\title{
Alkanes in a number of hydrothermal systems of the Russian Far East
}

\author{
Valery Poturay ${ }^{1, *}$ \\ ${ }^{1}$ Institute for Complex Analysis of Regional Problems FEB RAS, 679016 Birobidzhan, Russia
}

\begin{abstract}
The article presents the results of research dedicated to saturated hydrocarbons in the hydrothermal systems of the Russian Far East. The research has revealed significant differences in molecular-mass distribution of alkanes in the hot springs with different temperatures and origin. Alkanes, contained in the most high-temperature fluid from deep wells in Kamchatka peninsula, have the thermogenic genesis. At the same time alkanes, contained in the continental hot springs, are formed as a result of chemical re-synthesis of organic residues. In the least hot waters, as well as in cold underground and surface waters, hydrocarbons with bacterial and vegetable genesis have been revealed.
\end{abstract}

\section{Introduction}

In hydrothermal systems the abiogenic and thermogenic formation of organic compounds is possible as a result of chemical reactions that are initiated by physicochemical parameters of the system. This is of fundamental importance for solving the issues related to the origin of life, considering that in early Earth, when there was no life, organic compounds could have only abiogenic genesis. Nowadays many scientists working in this field are paying close attention to geothermal regions due to rapid development of ideas about hydrothermal scenario of the biosphere origin [1-5]. In their opinion, hydrothermal systems are the most suitable environment for the life origin. In this regard, the identification of organic substance origin and the study of mechanisms of hydrocarbon formation in hydrothermal systems is an important task. In addition, such studies can be used for deeper understanding of processes of hydrothermal oil generation. For these purposes a group of organic compounds as saturated hydrocarbons or normal alkanes (nalkanes or alkanes) is suitable. This is the only group of biogenic components that is chemically stable and retains its structure as well as all biological and geochemical information.

The purpose of this study is to reveal the composition of n-alkanes and to estimate their molecular mass distribution in hydrothermal systems of the Russian Far East, as well as to determine their origin.

\footnotetext{
* Corresponding author: poturay85@yandex.ru
} 


\section{Objects and methods of research}

To study alkanes in the hydrothermal fluid, we have selected five hydrothermal systems, differing in temperature and formation conditions. Two of them, Mutnovskaya and Paratunskaya, are located on the peninsula of Kamchatka (Fig. 1a.). These are hightemperature waters and steam-water mixture $\left(82-175^{\circ} \mathrm{C}\right)$, which are brought to the surface by deep boreholes (depth from 1080 to 1800 meters). Inside the Mutnovsky area, it is a condensate of steam-water mixture taken from the borehole in North Mutnovsky thermal field (alkaline solution with a temperature of $95^{\circ} \mathrm{C}$ ) and from the borehole within Mutnovsky geothermal power station (acidic solution with a temperature of $175^{\circ} \mathrm{C}$ ). Their formation occurs under conditions of a sharp thermogradient regime due to close to the surface magmatic chamber. Data on organic matter have been published in a number of works [6-12].

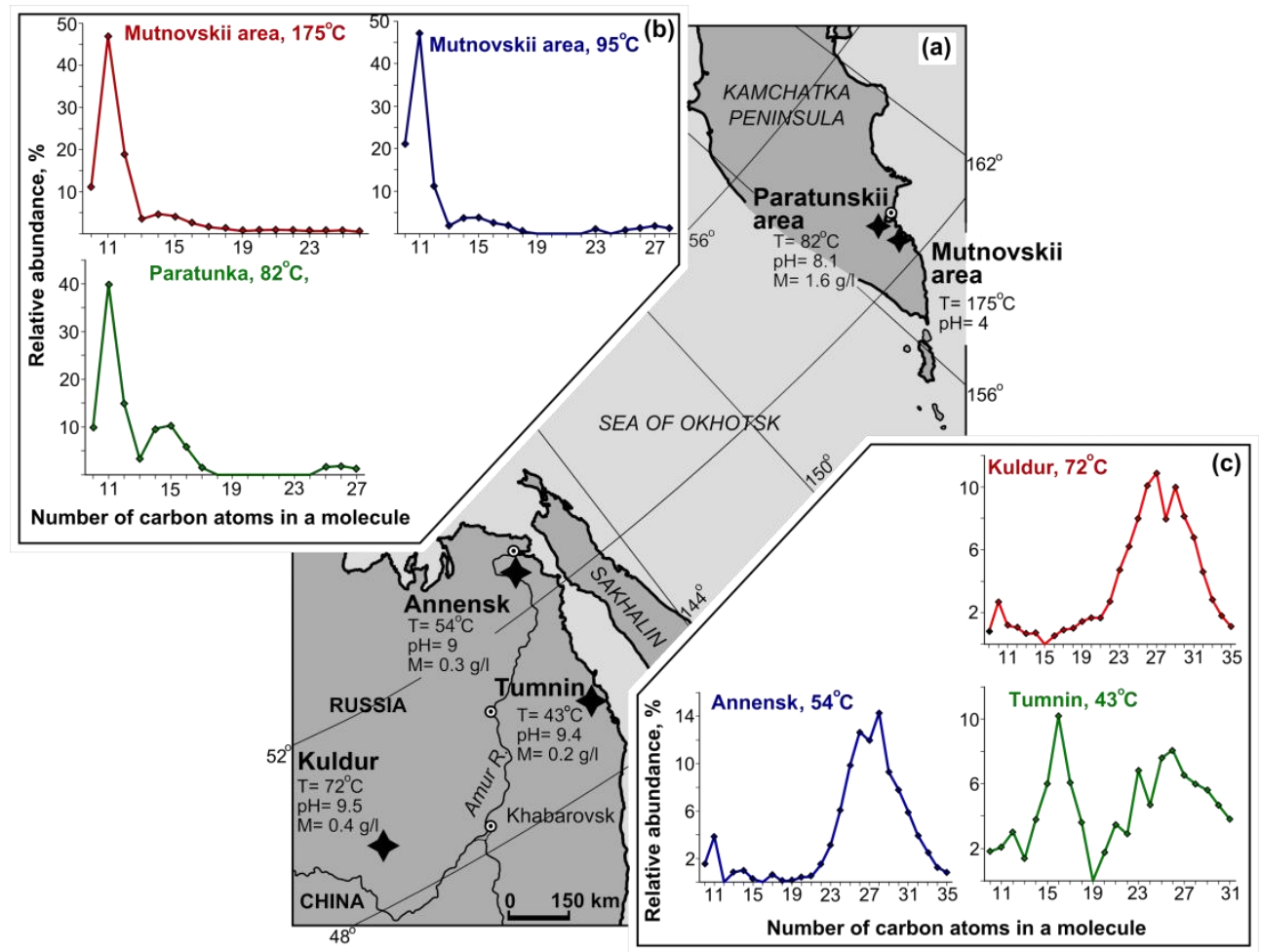

Fig. 1. A survey map with the location of hydrothermal systems under study (a) and graphs of alkane distribution in thermal waters and condensate of steam-water mixture from the boreholes of peninsular (b) and continental (c) hydrothermal systems.

In addition to peninsular geothermal regions, we researched three hydrothermal systems, located in the continental part of the Russian Far East. They are Kuldur, Annensk and Tumnin hydrothermal systems (Figure 1a). These thermal waters have a moderately high water temperature $\left(46-73^{\circ} \mathrm{C}\right)$, and discharge in shallow boreholes (100 to $500 \mathrm{~m}$ depth).

These waters have an infiltration origin. High temperature is provided by a normal thermal gradient. We also studied cold waters surrounding these hot springs. The organic matter containing in cold and hot waters we have already studied [13-15].

Water samples were taken from boreholes, in which the thermal water and steam-water mixture are penetrated, and from cold underground and surface water. Utensils made of 
dark glass were used for taking these samples. Organic substances' concentrating was carried out by solid-phase extraction with using the ODS-C18 cartridge. The analysis was carried out by means of capillary gas chromatography in combination with mass spectrometry with the help of Shimadzu GCMS-QP2010S and Shimadzu GCMS-QP2010 ultra devices in the laboratory of the Khabarovsk Territory Center for Environmental Monitoring and Prediction of Emergencies (analyst - V.L. Rapoport) and in the laboratory of ICARP FEB RAS (analyst - V.A. Poturay).

\section{Results and discussion}

Alkanes are present in all studied hydrothermal systems. Their share in the composition of medium volatile organic matter is rather significant (from 15 to 50\%). The remaining groups of organic compounds consist of aromatic hydrocarbons, alcohols, aldehydes, carboxylic acids and their esters, nitrogen-containing compounds, terpenes, and etc. The molecular-mass distribution of alkane homologues and the CPI and OEP indices were used as criteria for determining the hydrocarbons genesis. CPI (Carbon Preference Index) is the ratio of odd alkanes to even ones in the high molecular weight region. OEP (odd-to-even predominance) is the ratio of odd homologues to the nearest even ones [16, 17].

\subsection{Eastern Kamchatka hydrothermal systems}

In the steam-water mixture and high-temperature solution from deep boreholes of Mutnovskaya and Paratunskaya hydrothermal systems the sharp predominance of low molecular weight alkanes $\left(<\mathrm{n}-\mathrm{C}_{22}\right)$ is observed. The content of $\mathrm{n}-\mathrm{C}_{10}-\mathrm{C}_{14}$ homologues reaches $85 \%$ (Fig. 1b). Bacteria synthesize low-molecular odd $n-C_{7}, n-C_{9}, n-C_{11}, n-C_{13}$ and $n-\mathrm{C}_{15}$ homologues with a maximum at $\mathrm{n}-\mathrm{C}_{9}$ and practically do not synthesize even $\mathrm{n}-\mathrm{C}_{8}, \mathrm{n}$ $\mathrm{C}_{10}, \mathrm{n}-\mathrm{C}_{12}$ and $\mathrm{n}-\mathrm{C}_{14}$ homologues. The ratio of even and odd alkanes is practically the same. The $n-\mathrm{C}_{10}-\mathrm{C}_{14}$ alkanes are not synthesized at all by hydrothermal biota [18]. Probably, the bulk of hydrocarbons are the product of thermocatalytic transformation of organic residues, which came as a result of water (steam) - rock interaction. This is indirectly confirmed by the fact that there are no even carboxylic acids (which are synthesized by bacteria) and other obviously biogenic components, such as steroids, ethers and terpenes.

The CPI and OEP indices also indicate the predominantly thermogenic genesis of alkanes in these systems. The only exception is $\mathrm{OEP}_{25}$, the value of which exceeds unity (1.6-1.7). Probably, an insignificant part of alkanes in the high-molecular region was formed with the possible participation of cyanobacteria.

\subsection{Continental hydrothermal systems}

In the waters of Annensk and Kuldur hydrothermal systems (temperature $54-73^{\circ} \mathrm{C}$ ) there is a sharp predominance of high molecular weight alkanes $\left(>n-C_{22}\right)$ over short-chain homologues $\left(<\mathrm{n}-\mathrm{C}_{22}\right)$ (Fig. 1c). The ratio of low molecular weight alkanes to highmolecular weight alkanes is $0.1-0.2$. The share of $n-C_{10}-C_{14}$ alkanes and alkanes having hydrobiont origin $\left(n-C_{15}, n-C_{17}\right.$ and $\left.n-C_{19}\right)$ are low.

The content of bacterial hydrocarbons ( $n-C_{16}, n-C_{20}-C_{24}$ ) is slightly higher (up to $17 \%$ ). The OEP indices have values close to unity. With a sharp predominance of high molecular weight alkanes, CPI index value is about unity. As a result of biogenic formation of high molecular alkanes, the predominance of odd components characteristic of higher plants would be observed. Probably, the formation of the main part of alkanes in these (waters may be due to chemical re-synthesis of decomposed residues of organic substances, 
especially of vegetable origin (taking into consideration the significant predominance of high molecular weight alkanes).

The distribution profile of alkanes in Tumnin thermal waters (water temperature $43^{\circ} \mathrm{C}$ ) is different. In this system is observed the dominance of alkanes (n-C16, n-C20-C24) formed with the participation of bacteria. Their share is $30 \%$. The $n-\mathrm{C}_{16}$ homologue is the dominant peak. In addition, with a uniform distribution of low- and high-molecular homologues, there is slight predominance of even alkanes. The value of the $\mathrm{OEP}_{23}$ index is higher than one (1.7). This allows us to assume that the main part of the alkanes here are bacterial.

\subsection{Cold waters}

We also studied alkanes in cold waters within continental thermal fields. Water samples were taken from shallow boreholes Water from these wells is used by people as table waters. In addition, water samples were taken from the Kuldur River (Kuldur field), the Amurchik creek (Annensk field) and the Chope creek (Tumnin field). In the cold underground waters of the Kuldur region, there is a significant amount of alkanes formed with possible bacterial involvement $\left(n-C_{16}, n-C_{20-24}\right)$. Their share reaches $40 \%$ and the maximum peak in the first fraction falls on the $n-C_{16}$ homologue. The OEP indices are less than one, which also indicates the biogenic, mainly bacterial, genesis of alkanes. In addition, there is a dominance of long-chain hydrocarbons and a weak predominance of odd homologues over even ones, which indicates the vegetable genesis of some alkanes. In the cold underground waters of the Annensk region is observed a weak predominance of odd homologues, however the share of alkanes of bacterial and planktonogenic origin is low, which indicates the significant participation of higher plants in hydrocarbons formation.

In cold surface waters the maximum peaks in the high molecular weight region fall on $\mathrm{n}-\mathrm{C}_{27}$ (heptacosane) and $\mathrm{n}-\mathrm{C}_{29}$ (nonacosane). This indicates a biogenic source of high molecular weight alkanes. This is also indicated by the CPI value, which varies from 1.4 in the Chope creek to 2.4 in the Amurchik creek.

\section{Conclusion}

In hydrothermal systems of the Russian Far East there is a variety of organic compounds that are representative of all major groups and classes of organic matter. Here prevail saturated and aromatic hydrocarbons, carboxylic acids and their esters, nitrogen-containing compounds, terpenes, aldehydes, and etc.

In the studied hydrothermal systems normal alkanes with $n-\mathrm{C}_{9}-\mathrm{C}_{35}$ composition were found. Their share in all organic components revealed in these waters is from 15 to $50 \%$. Significant differences were found in the distribution of alkanes in hydrothermal systems having different temperatures and formation conditions. In the high-temperature fluid from deep boreholes in Kamchatka, the main part of hydrocarbons was formed as a result of thermogenic processes under the influence of high temperature and pressure (the ratio of low molecular weight alkanes to high molecular weight alkanes is from 15 to 40). In thermal waters from shallow wells of the continental part of the south of the Far East (Kuldur and Annensk thermae), alkanes were formed as a result of chemical re-synthesis of residues of decomposed organic matter having vegetable origin (the CPI index is $0.9-1$, the ratio of low molecular weight alkanes to high molecular weight alkanes is 0.1-0.2). Thermal waters with a low water temperature (Tumnin) are characterized by a separate type of molecular-mass distribution of hydrocarbons. These waters contain alkanes formed as a result of bacterial activity (the sum of $\mathrm{C}_{16}, \mathrm{C}_{20-24}$ homologues reaches $30 \%$ and the $\mathrm{OEP}_{23}$ index reaches 1.7). 
In cold groundwater and surface waters of the continental hydrothermal systems the alkanes have predominantly biogenic origin. The dominance of alkanes, having both vegetable and bacterial genesis, is observed here.

\section{References}

1. D.W. Deamer, First Life (University of California Press, Berkeley CA., 2011)

2. N.G. Holm, E. Andersson, Astrobiology, 5 (4), 444-460 (2005)

3. V.N. Kompanichenko, Origins Life Evol B, 42 (2-3), 153-178 (2012)

4. V.N. Kompanichenko, Thermodynamic Inversion: Origin of Living Systems (Springer International Publishing, Cham, 2017)

5. A.Y. Mulkidjanian, A.Yu. Bychkov, D.V. Dibrova, M.Y. Galperin, E.V. Koonin, PNAS, 109 (14), 821-830 ( 2012)

6. O.K. Bazhenova, O.A. Arefiev, E.B. Frolov, Org. Geochem., 29 (1-3), 421-428 (1998)

7. E.M. Galimov, V.S. Sevast'yanov, A.I. Kamaleeva, O.V. Kuznetsova, I.V. Konopleva, L.N. Vlasova, G.A. Karpov, Geochem Int, 53 (12), 1019-1027 (2015)

8. V.A. Isidorov, I.G. Zenkevich, G.A. Karpov, J Volcanol Seismol, 13 (3), 287-293 (1992)

9. V.N. Kompanichenko, V.A. Poturay, G.A. Karpov, J Volcanol Seismol, 10 (5), 305319 (2016)

10. V.N. Kompanichenko, V.A. Poturay, K.V. Shlufman, Origins Life Evol B, 45 (1-2), 93-103 (2015)

11. A.E. Kontorovich, S.B. Bortnikova, V.A. Kashirtsev, E.A. Kostyreva, A.N. Fomin, G.A. Karpov, Russ Geol Geophys, 52 (8), 768-772, (2011)

12. B.R.T. Simoneit, D.W. Deamer, V.N. Kompanichenko, Appl. Geochem., 24, 303-309 (2009)

13. V.N. Kompanichenko, V.A. Poturay, Tikhookean Geol, 34 (4), 96-107 (2015) In Rus

14. V.A. Poturay, Geochem Int, 55 (4), 393-400 (2017)

15. V.A. Poturay, Izv Tomsk Polytekh Univer, 324 (3), 44-52 (2014) In Rus

16. J.M. Hunt, Petroleum geochemistry and geology (San Francisco: W.H. Freeman and Company, 1979)

17. K.E. Peters, C.C. Walters, M.J. Moldowan, The Biomarker Guide (Cambridge: Cambridge University Press, 2005)

18. N.A. Shulga, V.I. Peresypkin, I.A. Revelskii, Oceanology, 50 (4), 479-487 (2010) 